\title{
KAKO SE ODRASLI UČIJO
}

Značilnosti učenja odraslih so bile vedno $v$ središču pozornosti izobraževalcev odraslih. $O$ učenju odraslih je bilo napisanega že zelo veliko, kljub temu pa neke enotne opredelitve nimamo. Načeloma velja, da je učenje otrok obvezno, formalno in standardizirano, učenje odraslih pa temelji bolj na prostovoljnosti in problemski usmerjenosti. Med smotri učenja odraslih pogosto omenjamo tudi razvoj neodvisnega in samostojnega posameznika. Izkušnje kažejo, da se odrasli običajno upirajo učnemu procesu, ki jim ne omogoča avtonomnosti ali ne ustreza njihovim potrebam in interesom. V pregledu teorij o učenju odraslih Merriam (2008) ugotavlja, da se glavne teorije in pristopi $k$ razumevanju tega učenja niti ne spreminjajo. Skozi vsa leta sta aktualni temi samostojnega učenja (self-directed learning) in transformativnega učenja, $v$ zadnjih letih pa $v$ ospredje prihaja predvsem pomen okoliščin, v katerih učenje poteka (kontekst učenja), kot je na primer učenje na delovnem mestu, pa tudi manj tradicionalne teme (za našo kulturo), kot je na primer pomen duhovnega in celostnega učenja. V zadnjem času pa temelji razumevanje učenja predvsem $v$ pripoznanju, da je učenje multidimenzionalen pojav, ki med seboj povezuje tako kognicije kot čustva in okoliščine, $v$ katerih učenje poteka.

Kateri so torej tisti glavni poudarki učenja odraslih?

\section{ODRASLI SE UČIJO Z DELOVANIEM}

Izobraževanje odraslih bi moralo biti vedno usmerjeno $v$ življenjske probleme. To je uče-

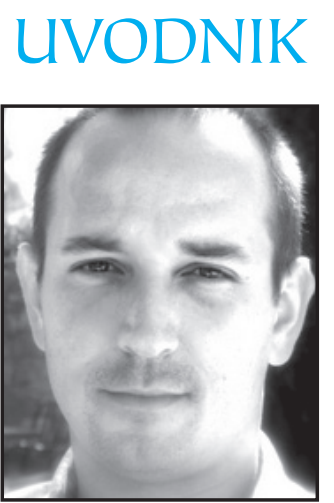

nje $z$ delovanjem, $z$ uporabo in na podlagi izkušenj. Odrasli niso nikoli le prejemniki novega znanja, ampak se pri učenju vedno navezujejo na svoje življenje in izkušnje, slednje osmišljajo in presojajo. Učenje odraslih je tako stalen proces raziskovanja, povezanega z ukrepanjem. Prevladujoče načelo je preizkušanje in iskanje novih poti, ne »bančni « način pridobivanja znanja, kot ga imenuje Freire. $V$ okoliščinah, kjer se udeleženec uči novih spretnosti, se z njimi tudi seznani in jih poskuša uporabiti $v$ realnih življenjskih okoljih, jih spreminja ali prilagaja. Odrasli želijo vse nove ideje, znanje ali spretnosti razumeti skozi svojo življenjsko izkušnjo in jih preizkusiti $v$ življenjskih okoliščinah. Povezovanje novega učenja s prejšnjimi izkušnjami je že uveljavljen način dela z odraslimi, o katerem sta pisala že Lindeman in Knowles. Tudi novejše raziskave potrjujejo pomembnost obdelave novih informacij ali izkušenj na podlagi predhodnih. V raziskavah na področju delovanja možganov so pokazali, da poskušajo možgani ob shranjevanju novih senzoričnih informacij slednje povezati s prejšnjimi informacijami oz. izkušnjami (Taylor in Lamoreaux, 2008). Te nove povezave pomenijo potencialno učenje, vendar pa je učinek učenja brez smiselnih povezav s predhodnimi izkušnjami majhen.

\section{SREDIŠČE UČENIA ODRASLIH SO ONI SAMI}

$\mathrm{Za}$ učenje $v$ začetnem izobraževanju pravimo, da temelji na učenju predvsem tistih stvari, ki jih bodo učenci/dijaki lahko uporabili kasneje v življenju. Prevladuje torej 
predmetna usmerjenost. Odrasli pa se pri učenju osredotočajo predvsem na neposredno uporabo naučenega. Glede na svoje vsakdanje obveznosti, ki so povezane z delovnim mestom, poklicem ali družino, si želijo znanje in spretnosti, ki jim bodo omogočili lažje spoprijemanje s temi področji njihovega življenja. Iz tega razloga skrb učitelja odraslih ni le v tem, da neko snov logično predstavi in izvede, temveč tudi v tem, da ob tem upošteva potrebe in interese udeležencev izobraževanja. Že Knowles (1980) je poudarjal, da se v andragogiki od učitelja odraslih pričakuje oblikovanje programa $z$ mislijo na odraslega udeleženca, kjer učiteljeva vloga ne bo (samo) $v$ poučevanju, temveč predvsem v usmerjanju in svetovanju pri učenju. V procesu oblikovanja programa moramo doseči soglasje z udeležencem glede usklajenosti ciljev programa in potreb posameznika. Če udeleženec dobi vtis, da njegova izkušnja ni ustrezno ovrednotena, se čuti zavrnjenega - ne samo kot udeleženec v izobraževanju, temveč tudi kot oseba v celoti. Kot rečeno - nove učne izkušnje se lahko osmislijo šele takrat, kadar jih lahko posameznik poveže s svojimi življenjskimi izkušnjami.

\section{UČENJE ODRASLIH JE SOCIALNO}

Merriam (2008) poudarja, da lahko o učenju govorimo $z$ individualnega in kontekstualnega vidika. Učenje je torej notranji proces, $k i$ se dogaja predvsem »v naših glavah«, kontekstualni vidik pa upošteva še dva pomembna elementa: interaktivno naravo učenja in strukturne vidike učenja, ki temeljijo $v$ sociološki teoriji. Pomembno za interaktivno dimenzijo učenja je spoznanje, da učenja ne moremo ločiti od konteksta, v katerem poteka. Na to opozarja tudi Knox (1977), ko ugotavlja, da izvirajo potrebe po učenju odraslih iz njihovih življenjskih situacij in medosebne komunikacije. Družbene vloge, ki jih prevzemajo odrasli, jih motivirajo $k$ iskanju novega znanja in boljši usposobljenosti za delovanje. Učenje odraslih torej temelji na izkušnjah lastnih in izkušnjah drugih, zato je za učno okolje odraslih običajno, da vsebuje dimenziji soudeležbe (participativnosti) in sodelovanja. Že Quigley (1997) je ugotovil, da se odrasli najraje učijo $v$ manjših skupinah, kjer se počutijo enakopravne in $v$ katerih svoje probleme in dileme razrešujejo na podlagi dialoga in iskanja skupnih rešitev. V taki skupini deluje učitelj kot enak med enakimi in ima predvsem vlogo posrednika, mentorja in usmerjevalca učenja. Vidik sodelovanja je še posebno pomemben $v$ programih, kjer preverjanje in ocenjevanje znanja ni glavni namen učenja. $V$ razmerah, ko učenje ni osrediščeno le na neki izdelek ali učni izid, v ospredje stopa predvsem proces učenja, ki se lahko bolj prilagaja potrebam in interesom skupine. Proces učenja tako postane enako pomemben kot učni izid, ravnotežje med njima pa je ob tem pogosto težko vzdrževati. Koliko svobode in vpliva lahko ima udeleženec pri izbiri vsebin in metod dela $v$ izobraževalnem programu? To so vprašanja, ki še danes burijo duhove andragogov.

\section{UČENJE ODRASLIH POMENI TUDI PRIDOBIVANJE NOVEGA ZNANIA IN SPRETNOSTI}

Prilagojenost izvedbe izobraževalnega programa potrebam, izkušnjam in interesom udeležencev lahko pomembno pripomore $k$ uspešnosti učenja. Vendar pa je učenje več kot le učni proces. Večje sodelovanje udeležencev pri izvedbi izobraževanja lahko vzame več časa in priprav, vendar pa mora na koncu voditi do konkretnih rezultatov, $k i$ naj bi se kazali tudi v pridobitvi določenih znanj ali kompetenc. Učenje mora vedno biti 
rezultat "pogajanja " med učiteljem in udeležencem. To pomeni, da odgovornost za določanje učnih vsebin ali ustreznih učnih metod ni niti samo na strani učitelja niti samo na strani udeleženca. Če sloni na prvem, pridobi izobraževanje prizvok avtoritarnosti ter transmisije znanj in spretnosti. Če pa bi učni načrti, metode ali kriteriji preverjanja in ocenjevanja znanja sloneli izključno na željah udeležencev, bi lahko bil iztržek učenja izrazito nepovezan, nesistematičen in neuporaben. Tako učenje bi se lahko hitro prevesilo bolj v druženje, izobraževalna vloga pa bi zbledela. Sprejetje načela ugotavljanja potreb odraslih brez pogajanja o utemeljenosti in umeščenosti teh potreb v izobraževalnem programu lahko izzveni $v$ prazno in pomeni, da je učitelj opustil odgovornost za učni proces in doseganje učnih ciljev v tem programu. Uspešna priprava učenja odraslih torej pomeni ohranjanje ravnotežja med učnim procesom in učnimi rezultati.

Sklenemo lahko z mislijo, da je učenje odraslih v samem središču prakse izobraževanja odraslih od temeljnega izobraževanja do višješolskega izobraževanja, izobraževanja na delovnem mestu, v muzeju, knjižnici, študijskem krožku ali delavnici. Nova spoznanja o značilnostih učenja odraslih niso koristna samo $z$ vidika našega razumevanja njihovega učenja, ampak širijo tudi naše razumevanje o vlogi učitelja pri tem učenju, vlogi učnega okolja in razmišljanje o učnih metodah, $s \mathrm{ka}$ terimi bi lahko njihovo učenje še spodbudili in obogatili. Vse to pa izboljšuje našo učinkovitost kot izobraževalcev odraslih.

\section{LITERATURA}

Brookfield, S. (1995). Adult learning: An overview. V A. Tuinjman (ur.), International Encyclopedia of Education. Oxford: Pergamon Press.

Knowles, M. S. (1980). The modern practice of adult education. New York: Association Press.

Knox, A. B. (1977). Adult development and learning. San Francisco: Jossey-Bass.

Merriam, S.B. (2008). Adult Learning Theory for the Twenty-First Century. New Directions for Adult and Continuing Education, 119: 93-98.

Quigley, A. (1997). Rethinking literacy education: The critical need for practice-based change. San Francisco: Jossey-Bass.

Taylor, K., Lamoreaux, A. (2008). Teaching with the brain in mind. New Directions for Adult and Continuing Education, 119: 49-59.

\section{Marko Radovan}

$$
\text { Marho Radrovar }
$$

